\title{
Does Cooperative Learning Increase Students' Motivation in Learning?
}

\author{
Van Dat Tran ${ }^{1}$ \\ ${ }^{1}$ Faculty of Education, An Giang University, Vietnam \\ Correspondence: Van Dat Tran, Faculty of Education, An Giang University, Vietnam. E-mail: tvdat@agu.edu.vn
}

Received: July 1, 2019

Accepted: July 24, 2019

Online Published: July 31, 2019

doi:10.5430/ijhe.v8n5p12

URL: https://doi.org/10.5430/ijhe.v8n5p12

\begin{abstract}
The present study examines the impacts of cooperative learning on the motivation for 72 second-year Vietnamese higher education students in the Research Methods in Education over the nine-week course. Seventy-two students were allocated into two smaller groups of 36 students. The same lecturer was assigned to teach these two groups of students. Cooperative learning was applied for the experimental group, while lecture-based teaching was utilized in the control group for the whole course. The study outcome demonstrated significant higher learning motivation in the experimental group than that in the control group. Implications for innovation in teaching methods and further research are suggested to popularize more cooperative learning for better learning outcomes.
\end{abstract}

Keywords: cooperative learning, small groups, learning motivation

\section{Introduction}

Cooperative learning is a teaching method in which small groups of students will be able to support each other to comprehend the lessons (Slavin, 2011). Five components of cooperative learning are positive cooperation, interaction tendency, individual responsibility, developing interpersonal and social skills, and quality of group performance. Cooperative learning enhances students' academic outcome, relational skills, and mindset when working collaboratively with other members in group (Chen, 2018; Johnson \& Johnson, 2008).

While discussion and cooperative learning could be a more effective teaching method for teachers to improve student learning outcome, many traditional teaching methods such as lecture-based, demo, and competitive learning tasks are still widely used in schools worldwide (Harman \& Nguyen, 2010; Nguyen, Terlouw, Pilot, \& Elliott, 2009; Thanh-Pham, 2011; Tran \& Lewis, 2012a). Cooperative learning which encourages students' collaboration for shared goal achievement and motivation could be a more beneficial alternative to lecture-based teaching (Johnson \& Johnson, 2009; Magnesio \& Davis, 2010; Mehra \& Thakur, 2008). Cooperative learning also enhances better relationships between participants and higher individual learning responsibility (Johnson \& Johnson, 2005), self-esteem, cohesiveness, and learning skills (Azian, Mellon, Ramli, \& Yusup, 2018; Johnson \& Johnson, 2006; Slavin, 2011). Cooperative learning has been known to increase students' learning motivation (Anderson \& Palmer, 2001; Brophy, 1987; Slavin, 1996; Johnson \& Johnson, 2009).

Motivation is considered as an indispensable element that offers guidance, inspires, and maintains constructive attitude toward a shared goal (Hancock, 2004). Pintrich, Smith, Garcia, and McKeachie (1991) argued that motivation includes three main elements: value elements (intrinsic and extrinsic goal orientation, and task value); self-efficacy elements (control perspective, individual perception for learning and performance); and the elements of effectiveness (test anxiety). The intrinsic goal orientation refers to the student's willingness to take part in a task or not due to the difficult level of the task, student's curiosity and ability. The extrinsic goal orientation considers if the student wishes to participate in a task because of marks, incentive, performance, and assessment. The task value is student's consideration of the tasks' attractiveness, importance, and usefulness. The control of learning belief is students' expectation of possible outcomes with their learning efforts. The self-efficacy for learning and performance is the expectation of learning outcome and performing on the assigned tasks for the shared project. "Anxiety" is student's negative thoughts and physiological arousals that disrupt performance.

Cooperative learning has been connected to better social network, and mindset development in students' social support, learning attitude and skills, self-belief and motives. Some significant researches (Bertucci, Conte, Johnson, \& Johnson, 2010; Johnson \& Johnson 2006; Johnson, 2009; Nichols \& Miller, 1994; Slavin, 2011) have proven that in cooperative learning, students demonstrated a better belief and performance of personal and academic collaboration than those of individualistic learning. Social collaboration has been known as a promotive for learning 
achievement, quality, and existence (Johnson \& Johnson, 2006). Cooperative learning also enhances better interconnection among students than those of competitive or individualistic learning (Johnson \& Johnson, 2005). Such positive relationship increases students' motivation and persistence to achieve the shared goals with satisfaction (Johnson \& Johnson, 2006; Nichols \& Miller, 1994; Slavin, 2011). Moreover, cooperative learning enhances better learning attitudes than those of competitive or individualistic learning environments (Johnson \& Johnson, 2005). Cooperative learning also develops skills for ways to solve problems, critical thinking, and interpersonal skills, especially when students share their ideas during learning tasks (Chen, 2018; Tran \& Lewis, 2012a; 2012b).

Furthermore, cooperative learning enables greater improvement in individual belief and confidence than those in competitive or individualistic learning (Johnson \& Johnson, 2005). Some studies (Bertucci et al., 2010; Kagan \& Kagan, 2009) have shown the fact that collaborative effort among group members enhanced higher self-esteem in students. The aforementioned studies share the same research outcomes of other former studies (Gillies, 2006; Nhu-Le, 1999; Vaughan, 2002; Zain, Subramaniam, Rashid \& Ghani, 2009) which have demonstrated that cooperative learning promotes advanced learning skills, better interconnectedness among students, higher self-esteem in learning, and better learning attitudes. In summary, cooperative learning should be employed to effectively enhance better engagement of students' learning attitude for a better learning outcome.

Studies' comparison between cooperative learning with other traditional teaching methods has shown that cooperative learning can enhance students' learning positive attitude for better learning outcome and knowledge comprehension. However, almost all research and literatures supporting the excellent benefits of cooperative learning were demonstrated in western education only. Therefore, it may not be persuasive whether cooperative learning can also be successfully implemented in other countries with different systems of society, religion, education, and culture. In addition, while cooperative learning should be considered as a better approach for different subjects in different academic levels, many studies only employed cooperative learning in Natural Sciences in primary and secondary education. In addition, not many studies have been investigated on the effective benefits of cooperative learning influencing on student learning in the higher education system in Vietnam. Studies of Nhu-Le (1999), Thanh-Pham (2010a), Thanh-Pham (2010b), Le (2010), Thanh-Pham (2011), Tran \& Lewis (2012b) also employed a qualitative, survey methodology to examine the impacts cooperative learning method on Vietnamese EFL (English Foreign Language) students' learning attitude and achievement. Aforementioned studies' findings also supported for the effective approach of cooperative learning in enhancing students' positive learning attitudes and academic achievement.

This study contributes to the literature with its empirical investigation of the effect of cooperative learning in Vietnamese higher education. Especially, this experimental study designed aims to argue if cooperative learning is more effective in enhancing students' learning attitude and motivation than lecture-based learning in higher education. The beneficial impacts of cooperative learning in better learning outcome and interpersonal connectedness mentioned in the literature have resulted to the primary hypothesis: Students who experienced cooperative learning method would achieve better learning motives than those learning in a lecture-based environment.

\section{Research Method}

\subsection{Participants}

This study employed a convenient sample of 72 second-year Vietnamese students in higher education from two original/current classes of the Faculty of Education at An Giang University. Class $1\left(n_{1}=36\right)$ was placed as the experimental group, and class $2\left(\mathrm{n}_{2}=36\right)$ was assigned as the control group. The treatment group consisted of 36 students ( 29 females and 7 males), and with an average age of 19.27. The control group included of 36 (27 females and 9 males), and with an average age of 19.36. Students of the two groups were asked to do a pre-test of the motivation and learning responsibility before the treatment. The analysis results of an independent t-test showed there were no significant differences in statistic on pre-test scores on the motivation between the treatment group and the control group (Table 1). The findings demonstrate similar pre-test scores of students in both groups before the commencement of the experiment. 
Table 1 . The results of independent t-tests between groups on pre-test scores

\begin{tabular}{|c|c|c|c|c|c|c|}
\hline \multirow[b]{2}{*}{ Motivation } & \multicolumn{2}{|c|}{$\begin{array}{c}\text { Experimental group } \\
(n=36)\end{array}$} & \multicolumn{2}{|c|}{$\begin{array}{l}\text { Control group } \\
\qquad(n=36)\end{array}$} & \multirow[b]{2}{*}{ tvalue } & \multirow[b]{2}{*}{ p value } \\
\hline & Mean & $\begin{array}{l}\text { Standard } \\
\text { Deviation }\end{array}$ & Mean & $\begin{array}{l}\text { Standard } \\
\text { Deviation }\end{array}$ & & \\
\hline \multicolumn{7}{|l|}{ Value components } \\
\hline Intrinsic goal orientation & 3.31 & .49 & 3.33 & .52 & 1.19 & $.276^{*}$ \\
\hline Extrinsic goal orientation & 3.24 & .51 & 3.25 & .53 & 1.67 & $.105^{*}$ \\
\hline Task value & 3.04 & .47 & 3.10 & .45 & 1.56 & $.116^{*}$ \\
\hline \multicolumn{7}{|l|}{ Expectancy components } \\
\hline Control beliefs & 3.26 & .54 & 3.29 & .57 & 1.37 & $.227^{*}$ \\
\hline $\begin{array}{c}\text { Self-efficacy for learning } \\
\text { and performance }\end{array}$ & 3.41 & .52 & 3.09 & .50 & 1.20 & $.261^{*}$ \\
\hline \multicolumn{7}{|l|}{ Affective components } \\
\hline Test anxiety & 3.01 & .49 & 3.03 & .51 & 1.60 & $.110^{*}$ \\
\hline
\end{tabular}

*No significant difference $(p>0.05)$

\subsection{Instrument}

To assess students' motivation, the motivational scale developed by Pintrich et al. (1991) was employed. This scale includes three main elements: value elements (intrinsic goal orientation, extrinsic goal orientation, and task value), expectancy elements (control beliefs, self-confidence and belief for learning and performance), and effective elements (test anxiety). The intrinsic goal orientation comprised 4 items (e.g. In this class, I expect a challenging course material so that I can be motivated to learn new things; in this class, I expect course material inspiring my curiosity, despite it may be difficult to comprehend; my satisfaction for this course is trying to comprehend the lesson as much as possible). The extrinsic goal orientation contained 4 items (e.g. My satisfaction for this class if getting a good grade right now; improving my overall grade point average is most important for me right now; therefore, getting a good grade is my most concern in this class; If I could, I wish to achieve better grades than most of the other students in this class). The task value comprised 6 items (e.g. I think I will be able to apply what I learn in this course in other courses). The control of learning beliefs contained 4 items (e.g. The learning material of the course can be comprehended with appropriate learning methods). The self-confidence and belief for learning and performance consists of 8 items (e.g. I am confident that I will achieve an excellent grade for this course). The text anxiety contained 5 items (e.g. I feel anxious of performing poorer than others).

Respondents showed on a five-point scale for each item. Items are graded 1, 2, 3, 4 and 5, respectively, for the responses Strongly Disagree, Disagree, Undecided/Neutral, Agree, and Strongly Agree. Table 1 shows the means, standard deviations, and Cronbach Alpha coefficient of internal consistency for the elements.

Table 2. Number of Items and Cronbach Alpha coefficient for the motivation

\begin{tabular}{ccc}
\hline Motivation & Number of Items & Cronbach Alpha \\
\hline Value components & & .72 \\
Intrinsic goal orientation & 4 & .69 \\
Extrinsic goal orientation & 4 & .81 \\
Task value & 6 & .67 \\
Expectancy components & & .78 \\
Control of learning beliefs & 4 & \\
Self-confidence and belief for learning & 8 & .71 \\
$\quad$ and performance & & \\
Affective components & & \\
Test anxiety & 5 &
\end{tabular}




\subsection{Design and Procedure}

The present study employed an experimental study design. In the study, the Pre-test-Post-test Non-equivalent Comparison-Group Design was utilized to examine the cause and effect relationship of the two main variables: the treatment variable - cooperative learning, and the outcome variable - motivation.

Before the academic year start, two intact higher education classes were chosen to join in the study before these classes' schedules were arranged for Research Methods in Education course for 9 weeks. The lecture-based teaching technique was randomly assigned to one class for the whole course; this class acted as the control group. The cooperative learning technique was employed to another class for their whole course; this class acted as the treatment group. Before the treatment, both groups took a pre-test on motivation. The course consisted of 9 chapters. Each chapter was delivered within 500 minutes in one week to each group by the same lecturer. The lecturer used the lecture-based teaching in logical steps to teach the students content of the whole course in the control group. The students in this class learnt the lesson with the whole class group. In the experimental group, the lecturer used the cooperative learning technique to guide the students to learn the whole course content. In this cooperative learning group, the lecturer employed the 9 following steps: (i) the lecturer delivered the learning materials and the objectives of learning content, (ii) the lecturer shared about the lesson structure, and the expected learning outcomes, (iii) the lecturer assigned students into groups, (iv) the lecturer moved students to assigned groups, (v) students received learning materials from the lecturer, (vi) students investigated and analysed their learning materials to obtain new knowledge, (vii) students supported each other and exchanged knowledge of the learning materials, (viii) students presented their lesson comprehension to the whole class, and (ix) the lecturer assessed students' understanding via their presentation.

The above 9-step procedure was replicated 9 times, once for each chapter of knowledge. Throughout the experiment, the two groups had classes separately with the same course content, for the same amount of time in the afternoons, and in the same classroom. To measure motivation, a post-test was conducted by all students of both groups after the treatment.

\subsection{Data Analysis}

To compare the groups' pre-test and post-test scores, an independent-samples t-tests were utilized. All data analyses were examined for significance at the .05 level.

\section{Results and Discussion}

Analyses of the t-test showed no significant difference of statistics in pre-test scores of the motivational components between the control group and the experimental one. However, the t-test analyses on the post-test scores delivered findings of significant differences between the experimental group and the control group on the motivational components (Table 3). Inspections of mean scores demonstrated significantly higher overall scores on the motivational components of the experimental group achieved than the control group.

Table 3. The results of independent t-tests between groups on post-test scores

\begin{tabular}{|c|c|c|c|c|c|c|}
\hline \multirow[b]{2}{*}{ Motivation } & \multicolumn{2}{|c|}{$\begin{array}{l}\text { Experimental group } \\
\qquad(n=36) \\
\end{array}$} & \multicolumn{2}{|c|}{$\begin{array}{c}\text { Control group } \\
\quad(n=36)\end{array}$} & \multirow[b]{2}{*}{ t value } & \multirow[b]{2}{*}{ p value } \\
\hline & Mean & $\begin{array}{l}\text { Standard } \\
\text { Deviation }\end{array}$ & Mean & $\begin{array}{l}\text { Standard } \\
\text { Deviation }\end{array}$ & & \\
\hline \multicolumn{7}{|l|}{ Value components } \\
\hline Intrinsic goal orientation & 4.31 & .56 & 4.01 & .57 & 4.77 & $.010^{*}$ \\
\hline Extrinsic goal orientation & 4.33 & .52 & 3.97 & .56 & 3.68 & $.036^{*}$ \\
\hline Task value & 4.12 & .59 & 3.68 & .49 & 4.76 & $.014^{*}$ \\
\hline \multicolumn{7}{|l|}{ Expectancy components } \\
\hline Control of learning beliefs & 4.47 & .51 & 4.03 & .52 & 3.34 & $.046^{*}$ \\
\hline $\begin{array}{l}\text { Self-confidence and belief } \\
\text { for learning and } \\
\text { performance }\end{array}$ & 4.51 & .58 & 4.07 & .56 & 4.01 & $.021^{*}$ \\
\hline \multicolumn{7}{|l|}{ Affective components } \\
\hline Test anxiety & 2.71 & .49 & 3.12 & .52 & 3.65 & $.040^{*}$ \\
\hline
\end{tabular}

*Significant difference $(p<0.05)$ 
The study results support the hypothesis that students who were instructed with the cooperative learning method will achieve better motivation and learning outcome than those who were taught through lecture-based method. The findings showed that frequent collaborative interaction among students for the learning tasks, and the students' activeness enhanced students' motivation in the experimental group. Deutsch (1949) shared that the students' social mutual dependence led to students' collaborative mutual interaction. With this collaborative interaction, students' actions in group influence the learning goals of each other via cooperative situations (Johnson \& Johnson, 2009). Students in collaborative group had more opportunities for mutual support, resources exchange, better interaction, and mutual influence which enhanced higher motivation for them than those in the control group (Johnson \& Johnson, 2008). Furthermore, cultural and social interactions in an active learning environment resulted in cognitive processes (Piaget, 1926; Vygotsky, 1978). Therefore, frequent mutual interaction of group members enabled students to effectively enhance new knowledge based the comprehended knowledge in collaborative interaction for the assigned tasks.

In the cooperative group, students developed their own potential via their observation, and the imitation of the more effective students' desired behaviours (Bandura, 1977; Schunk, 2007). The same studies result from learning theory constructivist supported that learners could manage the construction of their own meaningful knowledge via interacting with their environment (Brooks \& Brooks, 1999; Dewey, 1991; Yager, 2000). Constructivist's perspective also shared that students improved their motivation due to their active knowledge acquirement (Driscoll, 2000; Marlow \& Page, 2005). Findings of this study consistently support previous research studies (Doymus, Karacop, \& Simsek, 2010; Sahin, 2010) which demonstrate the cooperative learning tasks enhance better motivation for learners.

Findings from many studies (Nhu-Le, 1999; Le, 2010; Sahin, 2010; Thanh-Pham, 2010a; Thanh-Pham, 2010b; Thanh-Pham, 2011; Tran \& Lewis, 2012b) show that most students liked working, discussing, sharing information, teaching, helping one another, and enjoying the cooperative context. These findings are significantly consistent with previous studies which argue that students in cooperative learning groups achieve better interaction between each other (Johnson \& Johnson, 2005; Vaughan, 2002), enhances learning skills and self-esteem (Johnson, 2009). In cooperative group, students had more opportunities to improve interpersonal skills (Bertucci et al., 2010), consider various solutions from different points of views, and experience achievement in learning (Moore, 2008), which resulted in these positive outcomes. Briefly, students' social, academic, and psychologic success led to their positive attitudes in learning (Johnson \& Johnson, 2008).

While traditional teaching, competition is used to motivate students' learning rather than cooperation, academic cooperation and engagement has been widely studied for its positive effect on students' learning in higher studies (Daura \& Durand, 2018). Slavin (1990) argued that the positive motivation for students in cooperative learning is an indispensable component that supports the success of learning outcome. In small groups, students clearly recognize the importance of their teammates' contribution toward success for the shared goals; therefore, they tend to support more for each other's learning.

Cooperative leaning also develops self-esteem for students, and motivates students' participation (Panitz, 1999; Tran \& Lewis, 2012b). Slavin (1990) emphasized better learning outcomes with cooperative efforts of whole group. Like many previous research findings, Heleen and Arnold (2018) found that students in groups with better cooperation and engagement could solve problems together more effectively. By helping each other, the students create a collaborative community that enhances each member's better performance (Chen, 2018). Cooperative learning reinforces student motivation by offering more freedom - a great motivator for their learning achievement. In cooperative learning, students not only can actively participate in the learning process (Slavin, 1990) but also in coordinating the class process and curricula construction (Maurice, Lai, \& Chan, 2018; Meier, \& Panitz, 1996). Cooperative learning empowers better motivation and a positive attitude for the learners.

In cooperative learning, Johnson \& Johnson (2009) supported the reinforcement of positive interaction between teacher and student. Rongrong \& Kusum (2018) also emphasized that teacher's support enhances students' self-confidence, and students' interest in learning, which indirectly contribute to students' better academic achievement. In cooperative learning, communications are opened. Students have more opportunities to exchange their points of views and collaboration with other students and their teacher intensely and personally. Teacher professionally creates natural socialization with students in activities of cooperative learning. While moving around the classroom, observing students' interaction, and facilitating the cooperative learning process, teacher is able to interact with each student personally. This very open and individual approach is important for teacher to offer suitable support to each individual. With the acknowledgement of teacher's care, students engage more in the classroom activities. Wentzel (1997) shared that caring teachers are described as those that demonstrate the free style 
of interaction and inspiring behavior in a unique manner. Cooperative learning enhances these characteristics in teachers. Better learning outcomes can be delivered by a warm; autonomy supportive style teacher (Goldberg, Foster, Maki, Emde, \& O'Kelly, 2001). Cooperative learning not only reinforces students' interpersonal skills, but also improves academic engagement, and students' social motivation.

While traditional classroom discourages student's interaction with its competitive environment; students' cooperation enhances better social support and mutual interest for each other (Johnson \& Johnson, 2008). In cooperative learning activities, students are well trained with necessary interpersonal skills to work cooperatively with deliberately mixed capability of group members. In this way, interaction and collaboration can be fostered among all members. In the dawn of 4.0 industrial societies, social skills in cooperative learning are essential to connect people and share new knowledge (Hariharasudan, \& Sebastian, 2018). Getting along and working with others is the most important knowledge and skill for students (Bredehoft, 1991). When the world is moving so fast with a huge amount of new knowledge and skills; sharing and cooperating has become more and more crucial ever. Effective communication and collaboration toward shared goals within diverse social structures is essential for success (Johnson \& Johnson, 1989). Therefore, cooperative learning in school is important to equip students with necessary skills for an advanced collaborative work force (Slavin, 1980).

In the field of science, effective group-work skill for shared goals is especially important. Most scientific discoveries were achieved by contribution of team members of scientists toward a shared value/goal. Obviously, complex problems could be solved easier with a group of scientists with diverse backgrounds. It is essential for schools not only to instruct students about scientific knowledge, but also to equip students with effective team work skills. That is why cooperative learning is an effective teaching/learning technique for advancing group-work skills to effectively achieve shared goals (Nesbit \& Rogers, 1997). Cooperative learning has supported the increased attendance in learning activities and an interactive classroom environment which enhances higher student's motivation, participation, and enjoyment (Treisman, 1983). With more engagement, and joys in the learning activities, students are more eager to participate in the assigned tasks and shared goals. Despite the repeated learning flows, when students work together in cooperative learning, it would become more interesting and enjoyable learning experience for students (Panitz, 1999).

\section{Conclusion}

Cooperative learning with interactive approaches advances the motivation in a sample of Vietnamese higher education students. This study has proven that the frequent collaborative interaction among students in the treatment group reinforced students' mutual collaboration for better learning motives. This study consistently supports for findings of the previous studies in different cultures that cooperative learning could be a more beneficial teaching method. Findings of this study equip Vietnamese teachers with more empirical support for implementing effective interactive techniques in teaching in order to enhance students' learning motivation and better learning outcome. Thus, cooperative learning is strongly proposed as a more effective pedagogical instruction technique in the demanding educational innovation in Vietnam, especially with the high demand for a better motivating learning environment for students. Cooperative learning in which students can actively acquire and implement the learnt knowledge is recommended to take place of the traditional teaching with passive lecture-based. Although findings for this study support the positive impact of cooperative learning on students' motivation, the sample of this study is limited in only 72 students. Therefore, later researches are recommended to examine the possible influence of cooperative learning on learning attitudes and motivation with bigger groups of participants. By that way, findings will be more reliable to widely generate the effects of cooperative learning. Together with very few research studies investigating the effectiveness of cooperative learning for higher education students in Vietnam, the findings of this study cannot be generated that cooperative learning is the best teaching method for all educational levels in Vietnam. Thus, more research on cooperative learning at different educational levels in Vietnam should be conducted.

\section{References}

Anderson, F. J. \& Palmer, J. (2001). The jigsaw approach: Students motivating students. Education, 109(1), 59-62.

Azizan, M. T., Mellon, N., Ramli, R. M. \& Yusup, S. (2018). Improving teamwork skills and enhancing deep learning via development of board game using cooperative learning method in Reaction Engineering course. Education for Chemical Engineers, 22, 1-13. doi.org/10.1016/j.ece.2017.10.002

Bandura, A. (1977). Social Learning Theory, Englewood Cliffs, NJ: Prentice Hall Regents.

Bertucci, A., Conte, S., Johnson, D. W. \& Johnson, R. T. (2010). The impact of size of cooperative group on achievement, social support, and self-esteem. The Journal of General Psychology, 137(3), 256-272. 
doi.org/10.1080/00221309.2010.484448

Bredehoft, D. J. (1991). Cooperative controversies in the classroom. College Teaching, 39(3), 122-126. https://doi.org/10.1080/87567555.1991.10532444

Brooks, M. G. \& Brooks, J. G. (1999). The Courage to be constructivist. Educational Leadership, 57(3), 18-24.

Brophy, J. (1987). Synthesis of research on strategies for motivating students to learn. Educational Leadership, 45(2), 40-48.

Bruner, J. (1966). Toward a theory of instruction. Cambridge, MA: Harvard University Press.

Chen, Y. (2018). Perceptions of EFL College Students toward Collaborative Learning. Canadian Center of Science and Education, 11(2), 1-4. http://doi.org/10.5539/elt.v11n2p1

Daura, F. T. \& Durand, J. C. (2018). What Role Do I Play in My Learning? A Study on the Academic Engagement of Higher-Education Students. European Journal of Education, [S.l.], 1(3), 53-67. doi: 10.26417/ejed.v1i3.p53-67

Deutsch, M. (1949). A theory of cooperation and competition. Human Relations, 2, $129-152$. doi.org/10.1177/001872674900200204

Dewey, J. (1991). Experience and education. In A. Boydston (Ed.), Johnson Dewey: The later works, 1938-1939, 1-62. Carbondale, II: Siu Press.

Doymus, K. Karacop, A. \& Simsek, U. (2010). Effects of jigsaw and animation techniques on students' understanding of concepts and subjects in electrochemistry. Education Tech Research Dev, 58, 671-691. doi.org/10.1007/s11423-010-9157-2

Driscoll, M. P. (2000). Psychology of learning for instruction. (2nd ed.). Boston: Allyan \& Bacon.

Gillies, R. M. (2006). Teachers' and students' verbal behaviors during cooperative and small-group learning. British Journal of Educational Psychology, 76(2), 271-287. doi.org/10.1348/000709905X52337

Goldberg, K., Foster, K., Maki, B., Emde, J. \& O'Kelly, M. (2001). Improving Student Motivation through Cooperative Learning and Other Strategies. (Dissertations/Theses, Saint Xavier University \& Skylight Professional Development Field-Based Master's Program Chicago, Illinois). [Online] Available: https://eric.ed.gov/?id=ED455464

Hancock, D. (2004). Cooperative learning and peer orientation effects on motivation and achievement. Journal of Educational Research, 97(3), 159-166. https://doi.org/10.3200/JOER.97.3.159-168

Hariharasudan, A. \& Sebastian, K. (2018). A Scoping Review on Digital English and Education 4.0 for Industry 4.0. Industry 4.0 Implication for Economy and Society, 7(11), 227. doi.org/10.3390/socsci7110227

Harman, G. \& Nguyen, T. N. (2010). Reforming teaching and learning in Vietnam's higher education system. In G. Haaland, M. Hayden \& T. Nghi (Eds.), Reforming Higher Education in Vietnam: Challenges and Priorities, 65-86. London: Springer. doi.org/10.1007/978-90-481-3694-0_5

Heleen, V. M. \& Arnold, B. B. (2018). Crossover of engagement in groups. Career Development International, 23(1), 106-118. doi: 10.1108/CDI-03-2017-0060

Johnson, D. W. \& Johnson, R. (2005). New Developments in Social Interdependence Theory. Genetic, Social, \& General Psychology Monographs, 131(4), 285-358. doi.org/10.3200/MONO.131.4.285-358 https://doi.org/10.3200/MONO.131.4.285-358

Johnson, D. W. (2009). Reaching out: Interpersonal effectiveness and self-actualization, Boston: Allyn \& Bacon.

Johnson, D. W. \& Johnson, F. (2006). Joining Together: Group Theory and group skills. (7th ed.). Boston: Allyn \& Bacon.

Johnson, D. W. \& Johnson, R. (2005). New Developments in Social Interdependence Theory. Genetic, Social, \& General Psychology Monographs, 131(4), 285-358

Johnson, D. W. \& Johnson, R. T. (2008). Social Interdependence Theory and Cooperative Learning: The Teacher's Role. In R. M. Gillies, A. Ashman \& J. Terwel (Eds.), Teacher's Role in Implementing Cooperative Learning in the Classroom, 9-37. New York, U.S.A: Springer. https://doi.org/10.1007/978-0-387-70892-8_1

Johnson, D. W. \& Johnson, R. T. (2009). An Educational Psychology Success Story: Social Interdependence Theory and Cooperative Learning. Educational Researcher, 38(5), 365-379. doi.org/10.3102/0013189X09339057 
Johnson, D.W. \& Johnson, R.T. (1989). Social skills for successful group work. Educational Leadership, 47(4), 29-33.

Kagan, S. \& Kagan, M. (2009). Kagan Cooperative Learning (1st ed.). San Clemente, CA: Kagan Publishing.

Lampe, J. R., Rooze, G. E. \& Tallent-Runnels, M. (1996). Effects of Cooperative Learning Among Hispanic Students in Elementary Social Studies. The Journal of Educational Research, 89(3), 187-191 https://doi.org/10.1080/00220671.1996.9941324

Le, T. T. (2010). Infusing Cooperative Learning into An EFL Classroom. English Language Teaching, 3(2), 64-77. https://doi.org/10.5539/elt.v3n2p64

Magnesio, S. \& Davis, B. H. (2010). A Novice Teacher Fosters Social Competence with Cooperative Learning. Childhood Education, 86(4), 216-223. https://doi.org/10.1080/00094056.2010.10523152

Marlow, B. A. \& Page, M. L. (2005). Creating and sustaining the constructivist classroom. (2nd ed.). Thousand Oaks, CA: Corwin Press.

Maurice, G., Lai, K. C. \& Chan, K. W. (2018). Implementing small class teaching in East Asia: Problems and possibilities. International Journal of Educational Research, ISSN 0883-0355. doi.org/10.1016/j.ijer.2018.10.004

Mehra, V. \& Thakur, K. (2008). Effects of Cooperative Learning on Achievement and Retention in Mathematics of Seventh Graders with different Cognitive Styles. Indian Educational Review, 44(1), 5-31

Meier, M. \& Panitz, T. (1996). Ending on a high note: Better endings for classes and courses. College Teaching, 40(Fall), 45-81. https://doi.org/10.1080/87567555.1996.9932344

Moore, K. D. (2008). Effective instructional strategies: From theory to practice. Thousand Oaks, CA: Sage Publications.

Mulryan, C. M. (1994). Perceptions of intermediate students' cooperative small-group work in mathematics. The Journal of Educational Research, 87(5), 280-291. https://doi.org/10.1080/00220671.1994.9941255

Nesbit, C.R. \& Rogers, C.A. (1997). Using cooperative learning to improve reading and writing in science. Reading and Writing Quarterly, 13(1), 53-71. https://doi.org/10.1080/1057356970130105

Nguyen, P. M., Terlouw, C., Pilot, A. \& Elliott, J. G. (2009). Cooperative learning that features a culturally appropriate pedagogy. British Educational Research Journal, 35(1), 857-875. doi.org/10.1080/01411920802688762

Nhu-Le, T. (1999). A Case Study of Cooperative Learning in Inorganic Chemistry Tutorials at the Vietnam National University-Ho Chi Minh City (Master dissertation, University of Simon Fraser, Canada). [Online] Available: http://www.ir.lib.sfu.ca/bitstream/1892/8731/1/b19483041.pdf (March, 19, 2010)

Nichols, J.D. \& Miller, R.B. (1994). Cooperative learning and student motivation. Contemporary Educational Psychology, 19(2), 167-178. https://doi.org/10.1006/ceps.1994.1015

Panitz, T. (1999). The motivational benefits of cooperative learning. New Directions for Teaching and Learning, 78(2), 59-67. https://doi.org/10.1002/t1.7806

Piaget, J. (1926). The language and thought of the child, New York: Harcourt Brace.

Pintrich, P. R., Smith, D. A. F., Garcia, T. \& McKeachie. (1991). A manual for the use of the motivated strategies for learning questionnaire. National Center for Research to improve Postsecondary Teaching and Learning, Ann Arbor, MI. https://doi.org/10.1037/t09161-000

Rongrong, Y. \& Kusum, S. (2018). Teacher support, instructional practices, student motivation, and mathematics achievement in high school. The Journal of Educational Research, 111(1), 81-94, doi: 10.1080/00220671.2016.1204260

Sahin, A. (2010). Effects of Jigsaw III technique on achievement in written expression. Asia Pacific Education Review, 12(3), 427-435. https://doi.org/10.1007/s12564-010-9135-8

Schreiber, L. M. \& Valle, B. E. (2013). Social constructivist teaching strategies in the small group classroom. Small Group Research, 44, 395-411. doi.org/10.1177/1046496413488422

Schunk, D. H. (2007). Learning theories: An Educational Perspective. (4th ed.). Upper Saddle River, NJ: Pearson Education. 
Slavin, R. E. (1990). Cooperative learning: Theory, research, and practice. (2nd ed.). New Jersey: Prentice Hall.

Slavin, R. E. (1996). Research on co - operative learning and achievement: What we know, what we need to know. Contemporary Educational Psychology, 21(4), 43-69. https://doi.org/10.1006/ceps.1996.0004

Slavin, R. E. (2011). Instruction Based on Cooperative Learning. In R. E. Mayer \& P. A. Alexander (Eds.), Handbook of Research on Learning and Instruction, 344-360. New York: Taylor \& Francis.

Slavin, R.E. (1980). Cooperative Learning. Review of Educational Research, 50(2), 15-342. https://doi.org/10.3102/00346543050002315

Tanel, Z. \& Erol, M. (2008). Effects of Cooperative Learning on Instructing Magnetism: Analysis of an Experimental Teaching Sequence. American Journal of Physics and Education, 2(2), 124-136

Thanh-Pham, T. (2010a). Group Composition of Cooperative Learning: Does Heterogeneous Grouping Work in Asian Classrooms? International Education Studies, 3(3), 12-19. doi.org/ 10.5539/ies.v3n3p12

Thanh-Pham, T. (2010b). Implementing a Student-Centered Learning Approach at Vietnamese Higher Education Institutions: Barriers under Layers of Casual Layered Analysis (CLA). Journal of Futures Studies, 15(1), 21-38.

Thanh-Pham, T. (2011). An Investigation of Perceptions of Vietnamese Teachers and Students toward Cooperative Learning. International Education Studies, 4(1), 3-12. https://doi.org/10.5539/ies.v4n1p3

Tran, V. D. \& Lewis, R. (2012a). Effects of Cooperative Learning on Students at An Giang University in Vietnam. International Education Studies, 5(1), 86-99. doi.org/10.5539/ies.v5n1p86

Tran, V. D. \& Lewis, R. (2012b). The effects of Jigsaw Learning on Students' Attitudes in a Vietnamese Higher Education Classroom. International Journal of Higher Education, 1(2), 1-13. doi.org/10.5430/ijhe.v1n2p9

Treisman, U. (1983). Improving the performance of minority students in college level mathematics. Innovation Abstracts, 5(17), 362-372.

Vaughan, W. (2002). Effects of Cooperative Learning on Achievement and Attitude Among Students of Color. The Journal of Educational Research, 95(6), 359-364 https://doi.org/10.1080/00220670209596610

Vygotsky, L. S. (1978). Mind in society: the development of higher psychological processes. Cambridge: Harvard University Press.

Wentzel, K. R. (1997). Student Motivation in Middle School: The Role of Perceived Pedagogical Caring. Journal of Educational Psychology, 89(3), 411-419. DOI: 10.1037/0022-0663.89.3.411

Yager, R. E. (2000). The Constructivist Learning Model. The Science Teacher, 67(1), 44-45.

Zain, Z. M., Subramaniam, G., Rashid, A. A. \& Ghani, E. K. (2009). Teaching Students' Performance and Attitude. Canadian Social Science, 5(6), 92-102. 